\title{
Surveillance of fish species composition using environmental DNA
}

\author{
Toshifumi Minamoto $\cdot$ Hiroki Yamanaka $\cdot$ \\ Teruhiko Takahara $\cdot$ Mie N. Honjo • \\ Zen'ichiro Kawabata
}

Received: 25 July 2011 / Accepted: 14 October 2011 / Published online: 3 November 2011

(C) The Author(s) 2011. This article is published with open access at Springerlink.com

\begin{abstract}
Prompt and accurate methods for assessing the species composition of given areas are indispensable in addressing the rapid loss of biodiversity. Here, we propose a method for the surveillance of fish species composition in freshwater using environmental DNA as species markers. First, the applicability of the method was demonstrated through aquarium experiments. DNA was extracted from $120 \mathrm{ml}$ aquarium water, and the degenerated primers targeting the fish mitochondrial cytochrome $b$ gene were used for amplification. PCR-amplified fragments were analysed by random cloning, and all species reared in the aquarium were detected. Next, this method was applied to natural freshwater environments. Water samples were collected from three sites in the Yura River, Japan; DNA was concentrated from 21 of environmental water, and then amplified and cloned. Up to four species of fish were detected by sequencing 47 randomly selected clones from a single water sample. Overall, the results were consistent with previous knowledge of fish habitat utilisation. Using
\end{abstract}

Handling Editor: Nisikawa USIO.

T. Minamoto and H. Yamanaka contributed equally to this study.

T. Minamoto $(\bowtie) \cdot$ T. Takahara · M. N. Honjo · Z. Kawabata Research Institute for Humanity and Nature,

Motoyama 457-4, Kamigamo, Kita-ku, Kyoto 603-8047, Japan

e-mail: minamoto@chikyu.ac.jp

H. Yamanaka

Department of Environmental Solution Technology,

Faculty of Science and Technology, Ryukoku University,

Otsu, Shiga 520-2194, Japan

T. Takahara

Institute for Sustainable Sciences and Development,

Hiroshima University, Higashi-Hiroshima,

Hiroshima 739-8530, Japan this method, the surveillance of fish species composition can be conducted less laboriously than with traditional methods.

Keywords Species composition surveillance . Environmental DNA (eDNA) · Fish · Freshwater . Mitochondrial cytochrome $b$ gene

\section{Introduction}

Information on the species composition of a given area is among the most fundamental and important aspects of biodiversity studies. Multiple impacts cause deteriorations in biodiversity, including habitat destruction, invasive alien species, overexploitation, climate change and pollution, which are directly or indirectly caused by human activities (UNEP 2007). Information on which species inhabit a given area is necessary for the conservation of biodiversity; thus, assessment of the presence/absence of each species is required within a practical time-and-effort scale.

Although freshwater comprises less than $3 \%$ of the total water volume on earth, approximately $10,000(40 \%)$ of the 25,000 known fish species inhabit freshwater for at least part of their lives (Nelson 1994). Freshwater ecosystems provide high habitat diversity within small areas; however, these systems can be easily affected by the anthropogenic activities. In fact, the rate of species diversity loss is particularly rapid in freshwater ecosystems (Naiman et al. 2006). Conventional species composition surveys accompanied by direct catches generally require laborious and time-consuming work, and therefore make difficult the timely assessment of biodiversity losses. As we cannot easily see underwater environments, we need to develop innovative, instantaneous methods for the surveillance of species composition. 
Recently, noninvasive methods in which environmental DNA (eDNA) from freshwater was used to detect targeted invasive species (bullfrog and Asian carp) were reported (Ficetola et al. 2008; Jerde et al. 2011). This information gave us an incentive to extend this method to acquire a more complete picture of fish species composition. Here, we tried to establish a method for detecting fish in a given environment using eDNA amplified with degenerated primer sets that target mitochondrial cytochrome $b$ genes and allow for the simultaneous detection of multiple species. First, we attempted to detect fish DNA experimentally from aquarium water, and second, we applied the method to field samples.

\section{Materials and methods}

\section{Aquarium experiment settings}

Five species of fish (Nipponocypris temminckii, Cyprinidae; Oryzias latipes, Adrianichthyidae; Lepomis macrochirus, Centrarchidae; Odontobutis obscura, Odontobutidae; and Pelteobagrus nudiceps, Bagridae) belonging to different families were collected from Lake Biwa and nearby streams in Shiga Prefecture, Japan. Fish were kept in a stock aquarium (40 1) for 1 week at $25^{\circ} \mathrm{C}$ and then transferred to the experimental aquarium. Three experimental aquariums (1, 2 and 31 each) were prepared, and 1, 3 and 5 species, respectively, were put into each aquarium (for details, see Table 1). After being kept for $48 \mathrm{~h}$ at $25^{\circ} \mathrm{C}, 120 \mathrm{ml}$ of aquarium water was collected and $12 \mathrm{ml}$ of $3 \mathrm{M} \mathrm{NaAc}$ $(\mathrm{pH} 5.2)$ and $250 \mathrm{ml}$ of ethanol were added. After water

Table 1 Fish used in the aquarium experiments

\begin{tabular}{|c|c|c|}
\hline Aquarium 1 & Aquarium 2 & Aquarium 3 \\
\hline $\begin{array}{l}\text { Nipponocypris } \\
\quad \text { temminckii }(521 \mathrm{mg})\end{array}$ & $\begin{array}{l}\text { N. temminckii } \\
\quad(430 \mathrm{mg})\end{array}$ & $\begin{array}{l}\text { N. temminckii } \\
\quad(454 \mathrm{mg})\end{array}$ \\
\hline \multirow[t]{7}{*}{$\begin{array}{l}\text { N. temminckii } \\
\quad(420 \mathrm{mg})\end{array}$} & $\begin{array}{l}\text { N. temminckii } \\
\quad(350 \mathrm{mg})\end{array}$ & $\begin{array}{l}\text { N. temminckii } \\
\quad(361 \mathrm{mg})\end{array}$ \\
\hline & $\begin{array}{l}\text { Oryzias latipes } \\
\quad(169 \mathrm{mg})\end{array}$ & O. latipes $(375 \mathrm{mg})$ \\
\hline & O. latipes $(163 \mathrm{mg})$ & O. latipes $(283 \mathrm{mg})$ \\
\hline & $\begin{array}{l}\text { Lepomis } \\
\quad \text { macrochirus } \\
\quad(413 \mathrm{mg})\end{array}$ & $\begin{array}{l}\text { L. macrochirus } \\
\quad(1495 \mathrm{mg})\end{array}$ \\
\hline & & $\begin{array}{l}\text { Odontobutis obscura } \\
(342 \mathrm{mg})\end{array}$ \\
\hline & & O. obscura $(272 \mathrm{mg})$ \\
\hline & & $\begin{array}{l}\text { Pelteobagrus } \\
\text { nudiceps } \\
\text { (2045 mg) }\end{array}$ \\
\hline
\end{tabular}

The weight of each fish is indicated in parentheses collection, fins of each fish were collected and stored in $70 \%$ ethanol. To confirm the absence of the fish DNA in the water prior to experiments, two negative control aquaria without fish and one positive control with two N. temminckii (corresponding to aquarium 1) were prepared, and eDNA was collected as described above.

\section{DNA extraction}

The ethanol-added water samples were centrifuged for $1 \mathrm{~h}$ at $10,000 \times g$ at $4^{\circ} \mathrm{C}$, and supernatants were discarded. The pellets were resuspended in $10 \mathrm{ml}$ of TE buffer and then reconcentrated by ultracentrifugation using an Amicon Ultra15 (30 kD; Nihon Millipore KK, Tokyo, Japan). Total eDNA was extracted using a DNeasy Blood and Tissue Kit (Qiagen GmbH, Hilden, Germany). The final volume of DNA solution was $100 \mu$ l. DNA from fish fins was extracted using a DNeasy Blood and Tissue Kit, and the final volume of DNA solution was $200 \mu \mathrm{l}$.

\section{Degenerated PCR primers}

The mitochondrial cytochrome $b$ gene fragments were amplified with degenerated primers L14912-CYB (5'-TTC CTAGCCATACAYTAYAC-3' ${ }^{\prime}$ Y $=\mathrm{C}$ or T) and H15149CYB (5'-GGTGGCKCCTCAGAAGGACATTTGKCCY $\mathrm{CA}-3^{\prime} ; \mathrm{K}$ and $\mathrm{Y}=\mathrm{G}$ or $\mathrm{T}$, and $\mathrm{C}$ or $\mathrm{T}$, respectively; Miya and Nishida 2000). These primers target a broad range of fish species and amplify 285 bp of DNA, which is generally constant among vertebrates. To examine the specificity of the primers, sequences of the full length of L14912-CYB (20 bases) and 20 bases from the $3^{\prime}$-end of H15149-CYB were compared with sequences of fish species. The average number of mismatches for 61 species in Lake Biwa (all species for which the sequence data of the target region were available, representing 19 families) was 3.8 (1.8 for L14912-CYB and 2.0 for H15149-CYB). Theoretically, 31 of 61 species can be amplified when two mismatches for each primer are allowed. For the five species used in the aquarium experiments, 4, 5.3, 4, 3 and 2 mismatches were found for $N$. temminckii, $O$. latipes, L. macrochirus, $O$. obscura and $P$. nudiceps, respectively. For $O$. latipes, because a large number of cytochrome $b$ sequences were available in the database, the average number of mismatches was calculated using 33 sequences obtained in Japan (Katsumura et al. 2009).

PCR amplification, sub-cloning and sequencing

The $25 \mu \mathrm{l}$ of PCR reaction mixtures contained $0.4 \mu \mathrm{M}$ of each primer, $0.1 \mathrm{mM}$ dNTPs, $1 \mathrm{U}$ of $\operatorname{ExTaq}^{\mathrm{TM}}$ DNA polymerase (Takara Bio, Tokyo, Japan) and $4 \mu \mathrm{l}$ of 
template DNA. PCR was performed with 35 cycles at $94^{\circ} \mathrm{C}$ for $30 \mathrm{~s}, 40-55^{\circ} \mathrm{C}$ for $30 \mathrm{~s}$ and $72^{\circ} \mathrm{C}$ for $30 \mathrm{~s}$; the annealing temperature was set at $40,45,50$ or $55^{\circ} \mathrm{C}$ to verify the most appropriate temperature for detecting various species. The amplified PCR products were separated by $1.5 \%$ agarose gel, and the target band (285 bp) was cut and purified using Wizard SV Gel and PCR Clean-Up System (Promega, Madison, WI, USA), and cloned into pGEM-T Easy Vector (Promega). The colony-direct PCR was performed with M13 universal primers, and the sequence was determined by a commercial sequencing service (Takara Bio). To check for the effect of annealing temperature on PCR selectivity, we amplified the eDNA of aquarium 3 and sequenced 92-94 colonies for each annealing temperature. Sixteen and 63 clones were randomly selected and sequenced for PCR using the eDNA of aquaria 1 and 2, respectively. The DNA samples derived from fish fins were amplified as above (annealing temperature $=50^{\circ} \mathrm{C}$ ) and then directly sequenced.

\section{Analysis of environmental samples}

Environmental water samples were collected from three sites (corresponding to sites 3, 5 and 7 of Minamoto et al. 2009) along the Yura River on 13 April 2011. The Yura River flows into the Japanese Sea from near the centre of the main island of Japan. Sites 3, 5 and 7 are located in the lower reaches, a run of the middle reaches and a dammed pool of the middle reaches, respectively. River surface water (2 1) was collected in plastic bottles and immediately transferred to the laboratory. The sample water was then filtered with a 3.0- $\mu \mathrm{m}$ Isopore membrane filter (TSTP04700; Nihon Millipore KK). The residue on the filter was suspended in $20 \mathrm{ml}$ of TE buffer. Re-concentration by ultracentrifugation and DNA extraction was performed as above. To improve the PCR sensitivity for environmental samples, $1 \times$ AmpDirect for Semi-purified DNA (Shimadzu Biotech, Kyoto, Japan) was used instead of ExTaq buffer, and the annealing temperature was set at $50^{\circ} \mathrm{C}$. The cloning, colony-direct $\mathrm{PCR}$ and sequencings were performed as above.

\section{Results}

Detection of the DNA of fish kept in aquaria

The results of the aquarium experiments demonstrated the feasibility of detecting multiple fish sequences simultaneously using degenerated primers. An amplified band of 285 bp was obtained by PCR using eDNA from fish reared in aquaria as a template, and no bands were found in the negative control experiments. The sequencing of 92-94 colonies for each annealing temperature indicated that temperatures of 40,45 and $50^{\circ} \mathrm{C}$ resulted in the detection of four species sequences, whereas only three species were detected at $55^{\circ} \mathrm{C}$ (Table 2). Most of the sequences (ca. $90 \%$ ) obtained at an annealing temperature of $55^{\circ} \mathrm{C}$ were those of $P$. nudiceps, showing stronger selectivity under higher annealing temperatures. Selectivity did not strongly differ among $40-50^{\circ} \mathrm{C}$ annealing temperatures. The combined data of the $40-50^{\circ} \mathrm{C}$ experiments $(61,3,1,7$ and 207 sequences of $N$. temminckii, O. latipes, L. macrochirus, $O$. obscura and $P$. nudiceps, respectively, were detected) showed that the sequences of heavier fish tend to be detected more frequently, although this trend was not significant (Pearson's correlation coefficient $r=0.76$; $p=0.14)$.

Although there was no temperature at which all species of aquarium 3 were detected, we adopted an annealing temperature of $50^{\circ} \mathrm{C}$ for the subsequent experiments using aquaria 1 and 2 because lower annealing temperatures generally cause increased nonspecific amplification. As a result, the sequences of all species reared in the aquaria were successfully detected (Table 2).

\section{Species detection from environmental samples}

This approach to fish monitoring using eDNA was applied to environmental samples obtained from three sites in the Yura River, Japan. Then 46-47 clones were randomly selected and sequenced for each sample. The sequences were identified by BLAST search, and each sequence was annotated based on similarity (Table 3). When the most

Table 2 Numbers of sequences detected under each condition

\begin{tabular}{|c|c|c|c|c|c|c|c|c|}
\hline \multicolumn{2}{|l|}{ Aquarium 1} & \multicolumn{2}{|l|}{ Aquarium 2} & \multicolumn{5}{|l|}{ Aquarium 3} \\
\hline Species name & $50^{\circ} \mathrm{C}^{\mathrm{a}}$ & Species name & $50^{\circ} \mathrm{C}^{\mathrm{a}}$ & Species name & $40^{\circ} \mathrm{C}^{\mathrm{a}}$ & $45^{\circ} \mathrm{C}^{\mathrm{a}}$ & $50^{\circ} \mathrm{C}^{\mathrm{a}}$ & $55^{\circ} \mathrm{C}^{\mathrm{a}}$ \\
\hline \multirow[t]{5}{*}{ Nipponocypris temminckii } & 16 & N. temminckii & 57 & N. temminckii & 23 & 15 & 23 & 8 \\
\hline & & Oryzias latipes & 5 & O. latipes & 0 & 1 & 2 & 1 \\
\hline & & Lepomis macrochirus & 1 & L. macrochirus & 1 & 0 & 0 & 0 \\
\hline & & & & Odontobutis obscura & 4 & 1 & 2 & 0 \\
\hline & & & & Pelteobagrus nudiceps & 65 & 75 & 67 & 85 \\
\hline
\end{tabular}

\footnotetext{
a Annealing temperature of the PCR experiment
} 
Table 3 Numbers of sequences detected in the environmental samples

\begin{tabular}{|c|c|c|c|c|c|}
\hline \multicolumn{2}{|l|}{$\begin{array}{l}\text { Site } 3 \\
\text { (lower reaches) }\end{array}$} & \multicolumn{2}{|l|}{$\begin{array}{l}\text { Site } 5 \\
\text { (mid-reaches: run) }\end{array}$} & \multicolumn{2}{|c|}{$\begin{array}{l}\text { Site } 7 \\
\text { (mid-reaches: dammed pool) }\end{array}$} \\
\hline Species name & No. of seq. & Species name & No. of seq. & Species name & No. of seq. \\
\hline Tribolodon hakonensis & 10 & N. temminckii & 20 & N. temminckii & 20 \\
\hline Nipponocypris sieboldii & 7 & T. hakonensis & 7 & Silurus asotus & 4 \\
\hline \multirow[t]{3}{*}{ Non-fish $^{\mathrm{a}}$} & 29 & Pelteobagrus nudiceps & 7 & T. hakonensis & 1 \\
\hline & & Cyprinus carpio & 4 & Non-fish ${ }^{\mathrm{a}}$ & 22 \\
\hline & & Non-fish ${ }^{\mathrm{a}}$ & 9 & & \\
\hline
\end{tabular}

${ }^{\text {a }}$ Sequences that seemed to be of non-fish organisms (see text for details)

similar sequence found by BLAST search was not that of a fish, the sequence was categorised as non-fish, and these sequences apparently contained human sequences. In total, six fish species were detected from the three sites.

\section{Discussion}

In this study, we succeeded in establishing a method for estimating species composition using eDNA with minimal disturbance of natural environments. We could detect the sequences of most fish species kept in the aquaria, and the experiments using river water samples showed that this method can be applied to environmental studies. To our knowledge, this is the first report of the detection of multiple vertebrate species by amplifying eDNA with degenerated primers. Using this method, we can estimate the fish species composition in given environments more easily and rapidly than is possible with traditional methods based on direct catches using nets, lines and traps, or by direct observations using video cameras. Although the new method could not detect all fish species from field water samples, far less effort would be required to increase the number of replicates to detect more species compared to conventional methods. The high efficiency of the new method facilitates the rapid, large-scale evaluation of species composition.

In the aquarium experiments, we were able to detect all fish species reared in the aquarium. However, the proportion of detection was slightly biased. Sequences of $N$. temminckii and P. nudiceps were frequently detected, whereas sequences of $O$. latipes and L. macrochirus were rarely found (Table 2). The proportion of detection may depend on several factors such as the body size of fish, the volume of secretions or the degree of homology with primers. The highest detection rate for $P$. nudiceps could potentially be explained by its highest homology with the primers, as described in Materials and Methods. To design more appropriate primers, it is important to consider the taxonomic coverage and specificity necessary for the purpose of surveillance, which can be supported by the use of bioinformatic tools (Ficetola et al. 2010).

The overall results (Table 3) of the experiments using environmental samples fit well with previous knowledge. For example, N. temminckii (formerly known as Zacco temminckii type B) and $N$. sieboldii (formerly known as Z. temminckii type A) are known to exhibit niche segregation, with $N$. sieboldii inhabiting relatively downstream areas (Hosoya et al. 2003). This pattern was consistent with our results, as we did not detect the two species in the same site. Tribolodon hakonensis (big-scaled redfin) is known to be distributed widely from the lower to upper reaches (Kawanabe and Mizuno 2001), and its DNA was detected from all three sites. Silurus asotus (Amur catfish) generally prefers gentle streams or pools, and thus the detection of its DNA from a dammed pool seems reasonable. All of the species detected have been reported as inhabiting the Yura River by the National Survey on the Natural Environment in Rivers and Watershores (species database is available at http://www3.river.go.jp/; in Japanese). Clearly, many more species should inhabit the sample sites, and the method needs to be improved to detect more species by combining other techniques such as DGGE, T-RFLP, microarray or high-throughput sequencing. In particular, the use of high-throughput sequencing achieved by next-generation sequencing systems can improve the performance of eDNA analysis of multiple species in the environment as reviewed by Valentini et al. (2009). This analysis approach does not require cloning, and a large number of sequences can be obtained from a single eDNA sample. Alternatively, eDNA may be amplified with multiple species-specific primer sets, corresponding to all the species that one is interested in. Independently of the approach used, species composition surveys using eDNA are fundamentally possible and epoch-making.

When using this kind of method (i.e. the detection of eDNA), one has to consider the survivability of the target DNA in the environment. How long the DNA survives in 
environmental water could depend on environmental factors such as water quality and UV radiation, and the length of the target sequence (target length $=285 \mathrm{bp}$ in this study). Furthermore, in environments in which water flows, the organisms that released the DNA may inhabit areas distant from the sampling sites. A previous study has shown that DNA fragments of ca. $400 \mathrm{bp}$ survive up to 7 days in environmental water at $18^{\circ} \mathrm{C}$ (Matsui et al. 2001). In addition, Dejean et al. (2011) demonstrated that the persistence of bullfrog and sturgeon DNA (target length $=79$ and $98 \mathrm{bp}$, respectively) was less than 1 month at $17^{\circ} \mathrm{C}$ (bullfrog) or $8-11^{\circ} \mathrm{C}$ (sturgeon). Minamoto et al. (2011) showed that a viral genome (target length $=78 \mathrm{bp}$ ) degraded approximately $70 \%$ per day at $25^{\circ} \mathrm{C}$. Considering these facts, water flow and the rapidity of the degradation of the target DNA should be taken into account when analysing environmental samples. However, this method would be applicable at least to qualitative surveys in closed freshwater systems and for whole-basin surveys with basin-wide sampling when accurate knowledge of fish location is not required.

Detection methods using eDNA are applicable to many other efforts such as the early detection of invasive species as shown by previous reports (Ficetola et al. 2008; Jerde et al. 2011) or searching for rare species, both achieved by designing target-specific primers, as well as the quantitative estimation of target species via detailed analysis of the relationship between eDNA and fish density. The labourand time-saving surveys of fish species composition made possible by analysing eDNA may also aid in the preservation of unknown endangered species that may otherwise go extinct without being recognised.

Acknowledgments This study was supported by the RIHN C-06 project from the Research Institute for Humanity and Nature, Japan. The authors thank the members of the project for their assistance and daily discussions on our study. We also thank Dr. G.F. Ficetola and an anonymous reviewer for their careful reading and useful comments on an earlier version of the manuscript. TM, HY, MNH and ZK are affiliated scientists of the Center for Ecological Research, Kyoto University.

Open Access This article is distributed under the terms of the Creative Commons Attribution Noncommercial License which permits any noncommercial use, distribution, and reproduction in any medium, provided the original author(s) and source are credited.

\section{References}

Dejean T, Valentini A, Duparc A, Pellier-Cuit S, Pompanon F, Taberlet P, Miaud C (2011) Persistence of environmental DNA in freshwater ecosystems. PLoS One 6(8):e23398

Ficetola GF, Miaud C, Pompanon F, Taberlet P (2008) Species detection using environmental DNA from water samples. Biol Lett 4:423-425

Ficetola GF, Coissac E, Zundel S, Riaz T, Shehzad W, Bessiere J, Taberlet P, Pompanon F (2010) An in silico approach for the evaluation of DNA barcodes. BMC Genomics 11(1):434

Hosoya K, Ashiwa H, Watanabe M, Mizuguchi K, Okazaki T (2003) Zacco sieboldii, a species distinct from Zacco temminckii (Cyprinidae). Ichthyol Res 50:1-8

Jerde CL, Mahon AR, Chadderton WL, Lodge DM (2011) "Sightunseen" detection of rare aquatic species using environmental DNA. Conserv Lett 4:150-157

Katsumura T, Oda S, Mano S, Suguro N, Watanabe K, Mitani H, Oota H, Kawamura S (2009) Genetic differentiation among local populations of medaka fish (Oryzias latipes) evaluated through grid- and deme-based sampling. Gene 443(1-2):170-177

Kawanabe H, Mizuno N (eds) (2001) Freshwater fishes of Japan. Yama-kei Publishers, Tokyo (in Japanese)

Matsui K, Honjo M, Kawabata Z (2001) Estimation of the fate of dissolved DNA in thermally stratified lake water from the stability of exogenous plasmid DNA. Aquat Microb Ecol 26:95-102

Minamoto T, Honjo MN, Uchii K, Yamanaka H, Suzuki AA, Kohmatsu Y, Iida T, Kawabata Z (2009) Detection of cyprinid herpesvirus 3 DNA in river water during and after an outbreak. Vet Microbiol 135:261-266

Minamoto T, Honjo MN, Yamanaka H, Uchii K, Kawabata Z (2011) Nationwide cyprinid herpesvirus 3 contamination in natural rivers of Japan. Res Vet Sci. doi:10.1016/j.rvsc.2011.06.004

Miya M, Nishida M (2000) Use of mitogenomic information in teleostean molecular phylogenetics: a tree-based exploration under the maximum-parsimony optimality criterion. Mol Phylogenet Evol 17:437-455

Naiman R, Prieur-Richard A, Arthington A, Dudgeon D, Gessner M, Kawabata Z, Knowler D, O'Keefe J, Leveque C, Soto D, Stiassny M, Sullivan C (2006) Challenges for freshwater biodiversity research : Science plan and implementation strategy. DIVERSITAS, Report No. 5. DIVERSITAS, Paris

Nelson JS (1994) Fishes of the world, 3rd edn. Wiley, New York

UNEP (2007) Global environment outlook 4. Progress Press Ltd, Valleta

Valentini A, Pompanon F, Taberlet P (2009) DNA barcoding for ecologists. Trends Ecol Evol 24:110-117 